Western University

Scholarship@Western

$11-12-2019$

\title{
Politics versus Policies: Fourth Wave Feminist Critiques of Higher Education's Response to Sexual Violence
}

Rita A. Gardiner Ph.D

The University of Western Ontario, rgardin2@uwo.ca

Michelle Shockness

Eastern University

Jennifer Almquist

Oregon State University

Hayley Finn

Western University, hfinn3@uwo.ca

Follow this and additional works at: https://ir.lib.uwo.ca/edupub

Part of the Educational Leadership Commons, Feminist, Gender, and Sexuality Studies Commons, Higher Education Commons, and the Higher Education Administration Commons

Citation of this paper:

Gardiner, Rita A. Ph.D; Shockness, Michelle; Almquist, Jennifer; and Finn, Hayley, "Politics versus Policies: Fourth Wave Feminist Critiques of Higher Education's Response to Sexual Violence" (2019). Education Publications. 274.

https://ir.lib.uwo.ca/edupub/274 


\author{
Abstract \\ Rita A. Gardiner, Western University, Canada \\ Michelle Shockness, Eastern University \\ Jennifer M. Almquist, Oregon State University \\ Hayley Finn, Western University, Canada
}

This article uses the lens of fourth wave feminism to examine media accounts of institutional and student responses in two cases of sexual violence at institutions of higher education. Competing discourses reveal a disconnect between what institutions say they do and students' actual experiences of the institutional handling of sexual violence cases. When policies, actions, and values are not fully aligned, institutions of higher education are unable to respond to societal and institutional injustices. Hence, recommendations for better alignment between institutional values and actions are proposed. 
How can fourth wave feminism expose and interrogate the misalignment between universities' espoused values and how some institutions respond to actual cases of sexual violence? In addressing this question, this article highlights Sara Ahmed's (2007) claim that universities "end up doing the document instead of doing the doing" (p. 590). In this way, institutional policies become what Ahmed (2006) described as non-performatives, that is, higher education institutions may adopt specific policies without fully committing to the organizational and operational changes necessary to meaningfully address sexual violence. When policies, actions, and values are not fully aligned, institutions of higher education are unable to respond to societal and institutional injustices like sexual violence (Ahmed, 2017). Alongside Ahmed, fourth wave feminism is the lens used to explore the phenomenon of sexual violence in higher education. Specifically, we use this lens to explore how the responses by two universities, one in Canada (York University) and one in America (Stanford University) to incidences of sexual violence, expose a misalignment among institutional policies, practices, and values.

Further, we argue this new wave of feminist theorizing and activism has much to offer research into sexual violence, not least because of its focus on collective action and calls for increased public discourse to expose institutional injustice. Our interest in this new wave of feminist theorizing and activism also stems from our positionality at various intersections of identity and experience, while also sharing a common commitment to moving the pendulum on women's equality in unacknowledged spaces and to the mobilization of this solidarity in experience. Jennifer's perspective is informed by her identity as a cisgender, White female with over 10 years of administrative experience in higher education and an academic background focused on understanding the dynamics of sexism and other systems of oppression within organizations. Michelle identifies as a cisgender, Black female of Caribbean descent, whose 
experience, practice, and scholarship has found resonance with third wave feminist thought and activism. Hayley identifies as a cisgender, White female. Informed by fourth-wave feminism, her research is rooted in gender, leadership, and education. Rita identifies as a mature, cisgender, White woman of English/Irish descent, who has been a feminist activist and scholar since the late 1980s. Our different feminist standpoints and lived experiences added a robustness to our thinking, enabling us to explore the issues from diverse perspectives.

In the following sections, we review relevant literature on sexual violence in higher education and compare earlier feminist responses with fourth wave feminist approaches to addressing gender-based violence. Feminist discourse analysis is discussed as a methodology through which to analyze the dynamics of gender-based violence as exemplified through two cases of sexual violence (one involving a Canadian university; the other involving a university in the United States), both of which drew national and international media attention. While neither case is wholly representative of the dynamics of sexual violence within institutions of higher education, each shares similarities with other publicly available narratives about sexual assault on campuses. These cases highlight Ahmed's (2006) notion of non-performatives, that is, the contradictions between what values universities say they will demonstrate and how they are perceived to act. We conclude with an exploration of the effects of these contradictions as well as recommendations for institutional change.

\section{A History of Feminist Responses to Gender-Based Violence}

There is a long history of feminist responses to gender-based discrimination in the United States and Canada. Prior to 1975, feminist activists coined the term 'sexual harassment' to describe the experience of women who were groped as they walked down the hallway or propositioned regularly in their daily work, but where no common name for these behaviors 
existed (Baker, 2008). Such behaviors were seen neither as systemic nor related, but simply as a matter of course, the price women had to pay to enter the workplace (Baker, 2008).

Over the past four decades since sexual violence was named and identified as a workplace problem, significant strides have been made to create more equitable workplaces, largely as a result of feminists agitating for change (Bacchi, 1999; Bacchi \& Goodwin, 2016). The strategies employed by feminists change over time. For example, during what is generally recognized as the second wave of feminism, an important strategy for change in the United States involved introducing laws and passing policies at every level from the corporate office to the federal government to prohibit sexual violence and ensure a swift response (Baker, 2008). With reference to the university, having these policies in place is important because "they provide an outline for what students can expect from their university after assault" (Streng \& Kamimura, 2015, p. 68). However, sexual violence policies tend to focus on the threat of violence, as opposed to perpetrated sexual violence itself (Streng \& Kamimura, 2015). These policies can result in university-sponsored action that places the onus on women to prevent violence by taking preventative steps to reduce the risk.

Second wave feminists often viewed sexual violence through a heterosexist lens (Wooten \& Mitchell, 2016). Although there were positive changes in laws in many states in the 1970s as a result of feminist activism, the prevailing public discourse "portrays men as ultimate aggressors and women as ultimate victims" (Wooten, 2016, p. 48). This has led to the perception of sexual violence in normative, heterosexual terms that dictate a specific framework for federal policy on university campuses (Wooten, 2016). Thus, one significant problem that affected second wave feminists' efforts to address sexual violence was that the language used created misperceptions that, to this day, obscure the complexities of institutional sexism. 
Further, Bacchi (1999) argued that the term "sexual harassment" has been used over time in different ways, which has affected how it is both understood and addressed. For example, sexual harassment has sometimes been defined simply as unwanted attention, or as innocuous flirtation, as if the behaviors are themselves neutral until defined by a recipient as "unwanted" (Bacchi, 1999, p.186). The problem with this definition is that it separates sexual harassment from other forms of identity-based harassment, such as claims of race discrimination, which "are deemed by their nature unwelcome" (Bacchi, 1999, p. 186). This language encouraged common misperceptions that minimize sexual harassment as subjective, suggesting the complainant had simply confused well-intentioned sexual attraction or flirtation with harassment. However, as Bacchi (1999) noted, the burden should not be on the victim to account for why such behavior is unwelcome.

Furthermore, considering how difficult many survivors find it to come forward at all, this approach could facilitate "victim-blaming responses" (Cantalupo, 2011, p. 264). Rather, it was determined that what was needed was an objective societal standard whereby any behavior that is judged demeaning or humiliating is perceived as harassment. Hence, Bacchi (1999) called for greater conceptual clarity, which meant seeing sexual harassment as women-hating behavior.

One problem with this focus on women, however, is that it served to negate the different ways in which sexual violence was experienced by different groups of individuals, which became an emphasis for third wave feminist activists. Because many third wave feminists, who grew up in a world with legislation to prohibit and address sexual violence then entered universities and workplaces, they shifted their theorizing and activism to proactively creating more welcoming, inclusive climates. The emphasis shifted to not only legislating against sexual violence, but also to addressing sexism as the root cause (Baker, 2008). However, addressing 
sexism proved difficult because it is deeply embedded in every level of social and institutional power structure. Finally, these early waves of feminist responses to sexual violence and harassment provide the foundation for the emergence of a new wave of feminist activism. Fourth wave feminism becomes a necessary iteration in confronting the challenges posed by sexual violence.

\section{Fourth Wave Feminism}

Differing in some significant ways from earlier feminist waves, fourth wave feminism exhibits at least three characteristics that highlight a misalignment between institutional policies and contemporary feminist politics. Although the boundaries of this fourth wave are fluid, we identify the following distinguishing features: 1) increasing public discourse on feminist issues to challenge sexism and misogyny, 2) advancing broad-based collective activism through digital media, and 3) attending to diverse contexts and intersectional differences.

Fourth wave feminism creates a bridge between theory and practice that allows for the collective action that was a part of second wave feminism's success, while building upon the insights gained from the more theoretically-nuanced work of third wave feminists. Thus, fourth wave feminism builds upon the theory and practice of earlier feminist waves creating a contemporary discourse enriched by diverse perspectives and standpoints and cognizant of global and local issues regarding injustice (Wrye, 2009).

Participation in this new form of feminist activism spans all genders, ages, and other aspects of identity, although the organizers at the forefront of fourth wave activism are primarily women in their late teens and twenties (Cochrane, 2013a). Unlike their predecessors, this group of activists grew up during a period largely dominated by post-feminist rhetoric where feminist goals of gender equity were generally claimed to have been reached (Cochrane, 2013a). 
Characterizing this new feminism, Laura Bates, founder of the Everyday Sexism Project, said, "I feel like it is really down-to-earth, really open... and it's very much about people saying 'here is something that doesn't make sense to me, I thought women were equal, I'm going to do something about it"” (cited in Cochrane, 2013b, para. 3).

In short, fourth wave feminist politics allow different voices to be heard and enable political action that addresses concerns at the local, national, and international level. Although fragmented, fourth wave feminism is highly successful at mobilizing others via social media, offering the potential for widespread dissemination and engagement across and beyond the confines of the university campus. This rapidly developing wave is emerging at a time of increasingly rapid exchange of ideas. For this reason, much of the knowledge production occurs in real time, via popular culture. While the present dearth of scholarly articles exploring fourth wave feminism is in part a function of the slow rate of academic publication, the nonpeer-reviewed, non-scholarly spaces in which what becomes theory before it is defined as such is developed and action occurs is also a defining characteristic and a critical strategy for the emergent fourth wave.

Additionally, the fourth wave feminist movement is characterized as both 'visible' and 'fragmented,' with 'diversity of purpose' and 'cacophony of voices,' as compared with previous iterations of feminism (Munro, 2013, p. 22). Engaging a multiplicity of voices, across large geographic distance strengthens this form of feminist activism. Another strength is the use of social media as a means to challenge and to mobilize (Munro, 2013; Solomon, 2009), such as tweeting and blogging (Baumgardner, 2011). New technologies enable activists to engage the mainstream media with feminist issues and critique, and to traverse and organize across borders (Cochrane, 2013b). Furthermore, social media allows this new generation of feminists to 
disseminate information swiftly and mobilize quickly. This new activism further boasts a number of approaches, including but not limited to online petitions or protests, and consciousness-raising through wide and immediate dissemination of shared experiences.

The result of the dissemination of shared experiences is an iterative, evolving process as engagement online allows for multiple voices to inform, censure, refine, develop, and challenge ideas and, ultimately, inform the activism that then proceeds to challenge systemic oppression on a number of fronts. Activism is in 'real-time,' across large geographic distance, and can reach and appeal to a variety of supporters. Linking common experiences further adds to this generative process whereby strategies that have been previously used to confront critical incidents may be strategically mobilized on a number of fronts, resulting in a strategic pattern of activism toward desired ends (Munro, 2013).

The emergence of online spaces as sites for feminist discourse has led to the creation of a 'call-out' culture (Munro, 2013). The nature of these virtual sites makes it possible to challenge and call-out sexism and other forms of oppression, when using other formats may be risky for marginalized populations. Rentschler (2014) specifically points to the growing use of social media by young feminists as a way to interrupt the cultural norms and practices that support sexual violence and harassment. Thus, social media platforms make it possible for feminists to directly intervene and expose the sexual harassment they witness, acts that would otherwise often remain unrecognized and unpunished (Rentschler, 2014). Feminists in this emerging fourth wave are able to leverage social media to directly call attention to and challenge misogyny (Munro, 2013; Rentschler, 2014).

This brief history of feminist responses to sexual violence and harassment, from first naming the behaviors to advocating for legal and policy changes to working to change societal 
norms, provides the foundation for the emergence of a new wave of feminist activism. This collective activism, grounded in social justice, may be better able to confront the systemic nature of institutional sexual violence because of its ability to mobilize people (Iverson \& Issadore, 2018). This mobilization is indicative of fourth wave feminism's appeal. As such, it emphasizes collective activism and public discourse so as to call out perceived institutional and societal injustices. Before exploring the specific cases, we provide a description of our methodological framework.

\section{Methodological Framework}

This conceptual article was informed by feminist critical discourse analysis (CDA). Lazar (2007) maintains that feminist CDA works at the nexus between critical discourse analysis and feminist studies. Its aim is to advance nuanced understandings of how power and ideology operate through discourse to reaffirm gender hierarchies. Its goal is emancipatory social change, which dovetails with the goals of fourth wave feminism. A fundamental aim of feminist CDA is to reveal how institutional power is both produced and resisted through discourses.

Similarly, Bacchi (2009) notes that it is through discourse that one can examine underlying assumptions and values that underpin policies and create particular ways of framing an issue (Bacchi \& Godwin, 2016). Moreover, attending to how discourses are employed and countered in organizations, and the wider public sphere, is central to considering the challenges fourth wave feminist action poses to institutions. Consequently, using critical discourse analysis is a powerful tool that can assist feminist activists in their fight for social justice.

In particular, feminist CDA is a suitable methodological framework for looking at how the media discuss sexual violence (Barca, 2018). By focusing on specific instances of sexual violence, and the different ways that universities and female survivors of sexual violence respond 
to the same instances, we obtain a deeper understanding of the fissure between institutional structures and individual actors. One of the key aspects of this discussion is that underlying structural injustices affect bodies differently with women being far more likely to experience sexual violence (Cantalupo, 2016; Iverson, 2006).

Following Baer's (2015) identification of digital platforms as important sites of feminist activism, we traced the discourses related to these two examples by reviewing relevant online news articles as well as Twitter feeds posted in Canada and in the United States, during the period of June 2016 to June 2017 following the June 3, 2016 viral online posting of the letter by the then 23-year-old woman known only as the Stanford victim or Emily Doe. We reviewed online articles by major Canadian news sources reporting on Mandi Gray's sexual assault and the aftermath, which occurred in 2015 and predated reporting on the Stanford rape victim's letter, although there was overlap in the timeline of media reporting in each country because of the criminal trials and aftermath of these cases. We also traced additional content referenced in Twitter posts and in online news articles as potentially valuable sites at the intersection of advocate perceptions and responses to each university's action.

After a short description of the two universities concerned, the following section examines these cases and spaces in detail. The cases highlight a misalignment between the stated aims of higher education institutions to provide safe communities, and the actual experiences of some students. These cases illustrate the discursive struggle occurring between a university's desire to uphold its reputation, and actions that illustrate how this institutional desire comes at a cost. 


\section{Case Presentations}

On the surface, Stanford University and York University appear to be two very different higher education establishments. One of the most prestigious and highly regarded US universities, Stanford was founded in 1885 through a large bequest by former California Governor and railroad magnate Leland Stanford and was established at a time when the ideal of the research university was taking shape (Stanford University, n.d). Leland Stanford's bequest has been instrumental in funding Stanford's history of innovative and ground-breaking achievements (Stanford University, n.d.). In contrast to Stanford University, York University, Ontario, is a public university that was established in the 1950s, at a time of unprecedented growth in Canadian student enrollment, to include programming that catered to students from a multiplicity of backgrounds, varied ages and generations, and different socio-economic backgrounds (York University, n.d.).

These universities are, therefore, very different in their institutional global status and student body. Additionally, they exist in two different national contexts. However, there were similarities in the institutional response to these cases of sexual assaults that occurred on their campuses. In fact, while there are some differences in the systems of higher education, the dynamics of sexual violence are similar in the U.S. and Canada, and the ways sexual violence is perpetuated and addressed is similar across institutions in both countries. The Stanford rape case, arguably the most publicized among cases of sexual assault on university campuses (Weikle, 2016), made international headlines as Stanford University grappled with the sexual assault of a then unconscious woman by a Stanford student on University property. York student Mandi Gray's assault occurred off campus. However, her dealings with York University's administration garnered much attention, both in traditional and social media. Finally, both 
institutions received widespread public condemnation for their institutional responses to these incidents.

\section{The Stanford Rape Case}

To understand what unfolded at Stanford University, it is important to situate this case in broader efforts across U.S. colleges and universities to increase their focus on sexual violence prevention and response. This emphasis stems from the interplay between Title IX of the 1972 Education Amendments, the Clery Act, and the reauthorization of the Violence against Women Act (Burleigh, 2014; Harris, 2016; Jessup-Anger, Lopez, \& Koss, 2018). Under federal guidance, institutions of higher education receiving federal funding were compelled to not only respond appropriately, but also to proactively address all forms of sexual misconduct. In this way, campus sexual violence was again brought to the forefront of national conversations. Further, in 2014, the Obama administration set a mandate to improve the situation across university campuses, highlighting epidemic proportions of campus sexual violence (Burleigh, 2014). However, the Trump administration appears to be rescinding some of the previous federal oversight around campus sexual violence (Brown, 2017; Jessup-Anger, Lopes \& Koss, 2018).

Data from the US Department of Education (2014) demonstrate that across the 7,066 institutions with 11,611 campuses surveyed, over 6,700 forcible sex offenses (rape and fondling) were reported. However, Sinozich and Langton (2014) suggested that $80 \%$ of rape and sexual assaults occurring among female students between 1995 and 2013 went unreported.

Lauded among the first universities to introduce a 'yes means yes' affirmative consent standard prior to its adoption as California law, Stanford University had come to see itself as a leader in addressing campus-based sexual assault (Dwoskin \& Svrluga, 2016). However, the following case suggests otherwise. 
On January 18, 2015, an unconscious 23-year-old woman was found, undressed from the waist down, unresponsive but breathing, behind a garbage dumpster near a Stanford University fraternity house. A short distance away, officers found a young man, a Stanford student, restrained by two graduate students, both of whom confirmed that they had come upon the assailant while he was assaulting the unconscious woman (Sanchez, 2016). During subsequent criminal proceedings, the perpetrator received a six-month jail sentence (LaGanga \& Levin, 2016). The full details of the case are widely available and unfolded publicly across various media outlets.

Although our focus is on Stanford's mishandling of this case, it is important to mention the powerful statement Emily Doe, survivor of the assault, read to her attacker in court. And finally, to girls everywhere, I am with you. On nights when you feel alone, I am with you. When people doubt you or dismiss you, I am with you. I fought everyday for you. So never stop fighting, I believe you...I hope that by speaking today, you absorbed a small amount of light, a small knowing that you can't be silenced, a small satisfaction that justice was served, a small assurance that we are getting somewhere, and a big, big knowing that you are important, unquestionably, you are untouchable, you are beautiful, you are to be valued, respected, undeniably, every minute of every day, you are powerful and nobody can take that away from you. To girls everywhere, I am with you. Thank you (cited in Baker, 2016, para. 68).

The full statement powerfully articulates the devastating effects and after-effects of the assault on the survivor's life and relationships, and though offered as a statement to her attacker, includes her appeal to other survivors and to the common experience and fight against those who 
'doubt and dismiss'. Though Emily Doe does not directly cite Stanford's inaction in her statement, her posting seemed to prompt a response from the university.

Following the online publication of her statement in June 2016, Stanford University posted details and defense of its actions. Citing its pride for the heroic efforts of the two graduate students who intervened, Stanford further stated that it "urges its students to do the right things and intervene" (Stanford University Communications, 2016, para. 2). Citing the "significant amount of misinformation circulating about Stanford's role" (Stanford University Communications, 2016, para. 3), the statement further references the university's position as a national leader in taking concrete steps to assure that cases are handled fairly and justly (Stanford University Communications, 2016). The statement concludes with the university contending that there is much that needs to be done to "create a culture that does not tolerate sexual violence in any form and a judicial system that deals appropriately with sexual assault cases" (Stanford University Communications, 2016, para. 4).

Stanford University's defense of its processes and lack of apology to Emily Doe have been viewed as face-saving measures denoting a lack of compassion, prompting a further backlash by student activists. One student organizer of Stanford's sexual assault prevention group contended that the university focused more on perfecting a particular image, rather than acknowledging that sexual assaults occur on its campus (Dwoskin \& Svrluga, 2016). Thus, the perception is that Stanford's impression management was more important than acknowledging any institutional wrongdoing. Student protesters also demanded that university administrators release the names of any Stanford students who, through the judicial process of the university, had been found responsible for sexual offenses (La Ganga \& Levin, 2016). 
Among digital platforms, \#StanfordKnows became an outlet for student engagement, information sharing, and action. This hashtag was used to communicate with mainstream media, circulate petitions, and increase pressure on administration. In particular, students utilized the platform to draw attention to what they perceived as the Stanford administration's ineffective policies and responses to sexual assault on campus. The tweets intentionally called out Stanford administrators as well as other groups viewed as complicit by student activists. One retweeted post, for example, demanded that Stanford "release the names of rapists" on campus, the names of students who have raped on campus and whom the university has neither punished nor identified, and included a link to an online petition.

These responses demonstrate students' use of social media to bring public awareness to the case, develop a network of support and call the university to account. Despite Stanford's contention that they are a national leader in addressing sexual assault on university campuses (Stanford University Communications, 2016), it is evident upon review of this case that student activists challenge the veracity of the university's assertion. The use of digital platforms to do so is also apparent in the York University case.

\section{The York University Case}

In contrast to the United States, until recently, policies for handling sexual violence at many Canadian universities did not exist (Alani \& Jeffery, 2015; Browne, 2014). Given that education is a provincial matter, there are no federal policies commensurate with those in the U.S. (Tamburri \& Samson, 2014), and until recently, no provincial legislation mandated universities to adopt formal processes (Kane, 2016). As a result, an estimated $90 \%$ of reported sexual violence cases on Canadian campuses were handled through informal processes (Chiose, 2016). Some institutions report that informal processes are less problematic for survivors 
because they avoid the scrutiny and interrogation that often accompany formal processes (Quinlan, 2017). However, new provincial legislation introduced in Ontario in January 2017 now mandates Ontario universities and colleges adopt formal processes for addressing sexual violence. The York University case is situated in this context.

On January 31, 2015, a York University doctoral student, Mandi Gray, was sexually assaulted by a fellow doctoral student (Ward \& Shahzad, 2016). In court, Gray testified that she had been forced to engage in oral sex and sexual intercourse by her perpetrator after a night out together with friends (Ward \& Shahzad, 2016). Gray's allegations were used to bring her perpetrator to trial and were upheld in court. The criminal trial eventually led to the perpetrator's conviction, although the decision is under appeal (Hasham, 2017). Following the assault in 2015, Gray also filed a complaint with the Human Rights Tribunal of Ontario (Hoffman, 2015b; Mehta, 2016), openly citing York University's mishandling of her case. She stated that York's actions ultimately resulted in her decision to quit her teaching assistantship and doctoral studies and to leave the institution (Hoffman, 2015b; Ward \& Shahzad, 2016).

While it is reported that a safety plan was developed and Gray was offered an escort after the assault, the actions of the university are perceived to place the onus on the survivor to avoid her perpetrator rather than taking proactive steps to limit his access to campus (Hoffman, 2015a). For example, to support York's logic that Gray should bear responsibility, reportedly, university administrators provided her with her perpetrator's schedule so she could take steps to avoid him. Further, the university is reported to have had little support in place to guide Gray through its institutional complaint processes (Hoffman, 2015a). Gray reported that she notified more than 15 staff and faculty members about her assault, but no one was able to provide her with practical answers about the measures that could be taken (Hoffman, 2015b). Gray noted that the 
university's policy on sexual assault led to her experiencing re-victimization by university processes (Hoffman, 2015a), consistent with Smith and Freyd's (2014) description of the doubleharm perpetuated through institutional betrayal.

In a 2016 statement following the conviction of Gray's perpetrator, York University confirmed their approval of a new sexual assault policy, which, it asserted, will better support student victims on campus. The university stated:

[w]e appreciate how challenging the criminal justice process is for survivors of sexual violence and we respect Mandi and others for their decision to pursue it... we are looking at how we can further strengthen measures to support survivors... Today's verdict may be helpful in that regard (Ward \& Shahzad, 2016, para. 23). However, neither the statement nor the new policy addressed the harm Gray experienced. Gray is now a fervent advocate of victims' rights and an unabashed critic of Canadian universities and their existing processes and policies to 'manage' sexual violence on campus. Her online presence offers an important lens through which to view her advocacy and the engagement, encouragement, and support fostered among partners as they engage efforts to confront Canadian universities.

Gray's online advocacy also includes exposing university policy and providing her online advocacy with real-time updates around institutional processes and their potential impacts. Her presence on Twitter offers a meeting place for fellow advocates and critics, and space for sharing information and engaging in joint and strategic efforts. Gray's engagement in social media also offers space for the consideration of intersectionality, systemic bias, and the impact of sexual violence on women's bodies. Gray and her followers have also used social media to circulate surveys and petitions, including the 'RAPEnomics' survey, through which Gray sought feedback 
from survivors about the financial burden they faced following their assault. The results of this survey, which was completed by 150 survivors, were presented to the Trudeau government along with invoices for a total of $\$ 7$ million in damages (McGillivray, 2017). As with the Stanford case, it is evident how feminist activists are able to use social media to respond publicly to sexual violence, form social networks, and try to bring the university and its systems to account.

\section{Discussion}

The cases presented here illustrate the discursive struggles around sexual violence between student activists and university leaders. What emerges is a contradictory dynamic that shows points of divergence between espoused values and the impact of university actions as experienced by students. This section considers the observations gleaned from the review of these two public cases and the extent to which the actions of York and Stanford Universities suggest a misalignment with the espoused aim of higher education institutions to foster safe communities. When it comes to dealing with sexual violence, the results of the analysis conducted in this article echo Ahmed's (2007) argument that universities spend more time "doing the document" than the actual doing (p. 590). This means that well-intentioned policies may be ineffective in addressing sexual violence in ways that are consistent with the expectations of students, particularly in the era of \#metoo.

By studying institutional responses to two cases of sexual violence, what emerges is a contradictory dynamic that illustrates a kind of institutional indifference. In considering sexual violence on U.S. college campuses, Sharp, Weaver, and Zvonkovic (2017) argued that student activism has forced institutions to take a serious look at the meaning and consequence of their responses to the issue. "Systematic dismissal and improper handling of sexual violence complaints" (Sharp et al., 2017, p. 7) have been cited among major criticisms levied by students. 
Students have refocused the conversation on the ethical responsibility of higher education institutions to support students who have experienced sexual violence in their use of social media. Despite this pressure, institutional indifference is apparent in both the tone and content of the responses from the institutions in these cases. For Stanford, the prescribed course of action places the onus on students to take more responsibility as active bystanders. This response deflects institutional responsibility and is further illustrative of Barca's (2018) assertion that "[i]n the context of sexual assault, the preference for choice over power as an explanation undergirds discursive patterns that suggest victim rather than assailant accountability” (p. 267). In addition, York University's reaction in the Mandi Gray's case speaks to an institutional reticence to take responsibility for what occurred through dispersion of responsibility leading to Gray's revictimization via a university process where the onus was on Gray to avoid her perpetrator as the primary means to creating 'safety' on campus. Both examples reveal the discursive struggle between a university's desire to protect its reputation, and its sensitivity to its students.

In response, fourth wave feminist action challenges institutions and their actions in multiple ways. First, as evidenced by the social media responses to each case, student activists, and their allies seek new ways to bring experiences of sexual violence into the realm of public discourse. Prior to the emergence of this new wave, individuals who were sexually assaulted often experienced such a strong sense of powerlessness and fear that they were reluctant to make a report or even seek support services (Baker, 2008). A recent study indicates that the underreporting of sexual violence can be as high as $95 \%$ with victims stating they do not report, not only out of fear of the assailant, but also out of fear of the university's response (Spencer, Mallory, Toews, Stith, \& Wood, 2017). However, in the examples of both Stanford and York there is a strong insistence by survivors that their experiences with sexual violence be brought to 
public attention. While this still places the onus for action on the person who has been victimized, the avenue available in fourth wave-inspired activism is one in which students can work together to shift how institutions respond to sexual violence by acting as agents of change and advocates against campus sexual violence to transform campus norms about "consent, prevention, support for survivors, and institutional response" (Krause, Miedema, Woofter \& Yount, 2017, p. 36).

This strategy becomes particularly important as institutions of higher education employ standardized processes of identifying, recognizing, and responding to sexual violence (Iverson \& Issadore, 2018), and place a high value on their external image. Not surprisingly, institutional responses favor case proceedings that have little transparency and no public record, effectively erasing the event altogether (Whitley \& Page, 2015). In both of our cases, institutional acknowledgement of the violence by the universities is narrow in scope and of little substance. Furthermore, in both instances, the sexual violence is described as pertaining to an individual aggressor rather than an expression of institutionalized sexism. This is seen in the coverage of the cases, much of which focuses on support for the individual who has been victimized or protection of the alleged perpetrator, reminiscent of Bacchi's (1999) critique of the portrayal of sexual harassment as merely the confusion of well-intentioned attraction or flirtation. Arguing the points of possible misunderstanding or misperception kept the coverage of these cases focused at the interpersonal rather than institutional level. The institutional response is tempered by a desire to uphold its individual reputation. Conversely, by sharing their stories openly, survivors are able to form a collective voice. This collective voice enables them to obtain strength from the realization that they are not alone. One reason we focus on the case of Mandi Gray is because she reported "she was impressed by the Stanford University sexual assault 
victim's eloquent expression of the trauma she experienced" (Donnelly, 2016, para. 10). This indicates how counter-discourses circulate, indicating, in this case, how fourth wave feminist activism may offer support to other survivors of sexual violence. In an era when neoliberal practices in higher education emphasize "survival of the fittest" (Levin, Aliyeva, \& Walker, 2016, p. 166), this empathetic camaraderie amongst women is laudable, especially in contrast to institutional responses to sexual violence that emphasize institutional self-preservation. The effects of this self-preservation are further compounded by institutional policies that ignore the gendered reality of women's lives (Dougherty \& Godstein Hode, 2016).

The binary logics of masculinity/femininity produce an organizational hierarchy where the "rational assumptions underlying sexual harassment policies may be inconsistent with the lived experience in organizational cultures" (Dougherty \& Godstein Hode, 2016, p. 1729). Even though many Western institutions have policies that address sexual violence on campus, students report difficulties in formally naming sexual violence via institutional procedures. It seems that there is an institutional silence, which serves to perpetuate ongoing sexism in the university (Whitley \& Page 2015). Each of the cases examined here reveals how, in different ways, each university put its institutional reputation before its duty to care for each students, fundamental to a caring, educational environment. One effect of each university's action is to attempt to silence those harmed. Yet Emily Doe and Mandi Gray resist this institutional silencing by sharing their experiences and, in so doing, tap into a collective voice. This willingness to share their stories is important, because the credibility of individual survivors is often subject to attack by institutional actors who do not see them "as verifiable sources of knowledge" (Whitley \& Page 2015, p. 42). But the shared strength created by a community of activists who support these women is difficult to ignore. Fourth wave feminism has encouraged women across the world to 
use social media platforms to explore the effects and after-effects of sexual violence. Through the strategy of collective action (Iverson \& Issadore, 2018), there is a greater possibility to transform the ways higher education institutions address the problem of sexual violence on their campuses.

This analysis of the misalignment between university discourses and fourth wave feminist activism is illustrative in showing how the latter explicitly challenges, or calls out sexism and misogyny. In the examples of Stanford and York, the visible activism across social media platforms served as an important strategy for challenging deficiencies in institutional approaches to sexual violence. Additionally, our analysis reveals a discursive struggle in relation to the language used to name sexual violence. Different countries and cultures may be more willing to use stronger language whereas others find such language too explicit. The discursive scripts that describe sexual violence influence how violent acts are perceived not only by the institution, but also by complainants (Ropers-Huilman, Williamsen \& Hoffman, 2016). We struggled with the question of which term to employ in this paper; we ultimately chose the term sexual violence, but recognized that this term may be seen as exclusionary. Language matters. Bbut who uses which term and in what context is also relevant to understanding the power of discourse in framing the issue.

This issue of framing is also important to understanding how institutions of higher education in the era of neoliberalism chose their responses. The institutional preference for brand preservation meant that York and Stanford were unable to ignore public calls for accountability by Doe, Gray, and their supporters. However, this might not always be the best strategy. Institutions where the mishandling of sexual violence received widespread media attention have faced the potential of decreased student applications and enrollment, as well as loss of alumni 
funding (Nelson, 2015). Further, because universities are obsessed with their academic reputation, and thus keen to avoid lawsuits, they perpetuate the belief that the only way to address cases of sexual violence is through closed-door, confidential processes. While this is often purported to be in the best interest of survivors, the emphasis on secrecy is potentially harmful both to survivors and other students whose future well-being may be at stake. It is not surprising that institutions choose to be cautious about how they handle cases of violence. However, that caution is seen by some feminist activists as contrary to the need for safe spaces for all students.

\section{Limitations}

A new wave of feminist activists is using online environments to amplify individual voices and publicize concerns about the harm of sexual violence. This public action is not without its downside. There are many examples of feminist activists who are publicly vilified for taking a stand against sexism and other forms of oppression in a rise of a dangerous form of misogyny that has the potential to silence others. Not addressing the negative ways hate speech has dominated some areas of social media is a limitation of our analysis.

Additionally, while an emphasis on intersectional inequalities could arguably have presented as another important characteristic of fourth wave feminism, it is notably absent, at least as evidenced through media coverage, in the examples of Stanford and York. While feminism in general and sexual violence in particular are part of a larger consciousness that situates sexism as intersecting with other forms of oppression, its absence is a limitation of our work and an important area for further inquiry. Race, sexual orientation, and other aspects of identity indicate an experience of victimization further compounded by discrimination and silencing. Our choice of examples led to a specific focus on women's bodies, and in particular, 
the bodies of Caucasian women. The fact that these were such visible narratives in popular media, despite what we know about the prevalence of sexualized violence against people of color and against people who identify as lesbian, gay, bisexual, queer and/or transgender suggests the silencing of other narratives. In this sense, the examples presented offer critical, but incomplete, insight into the dynamics of sexual violence in higher education. Although beyond the scope of this article, we would suggest this is a critical area for further academic consideration.

\section{Recommendations and Conclusion}

This article exposes critical gaps between what institutions of higher education say they value versus how they act. Both Stanford and York, along with many colleges and universities across Canada and the United States, espouse a commitment to improving sexual violence response and prevention. Currently, the majority of sexual violence prevention strategies are "brief, psycho-educational programs" focused on increasing student and staff knowledge or changing attitude (DeGue et al., 2014, p. 347). However, none of these programs has shown evidence of effectiveness in preventing sexually violent behavior (DeGue et. al., 2014). By tracing the feminist activism that emerged in response to two public cases, it becomes clear that students expect and are calling for institutions to do better.

Although the focus is on two cases, these are not unique or localized concerns, and the prevalence of sexual violence at institutions of higher education in Canada and the United States must be addressed. Additionally, the feminist activism surrounding the specific cases of Stanford and York reveals new strategies and tactics, including the use of new platforms, by an emerging fourth wave feminist activism and beyond these two cases. Each example is indicative of a new feminist wave of student activism that criticizes society broadly and colleges and universities 
more specifically for being inadequately prepared to address the realities of sexual violence in the 21st century (Ahmed, 2017; Whitley \& Page, 2015).

What becomes evident from the specific analysis of cases at Stanford and York, particularly when combined with a broader scan of the current social context, is that institutions of higher education have an opportunity—and an obligation— to recalibrate their response to sexual violence. Following are four specific recommendations to better align politics and policies in ways that more meaningfully address sexual violence:

Develop a more inclusive perspective. In the evolving context of higher education, institutions tend to perpetuate a homogeneous perspective of students and their needs when establishing policies and procedures related to sexual violence and harassment (Harris, 2016; Spencer et al., 2017). This homogeneity is centered on white, masculine, and heteronormative experiences, which obscure the complexities of students' identities and experiences (Harris, 2016). While the cases presented here are consistent with this more normative framework, the broader review of fourth wave feminist activism challenges the idea that a homogeneous perspective will adequately encapsulate a range of experiences. Thus, this recommendation is informed less by what we saw and more by what we did not see in our review of cases that have received media attention. Emerging literature focused on current best practices argues that a more inclusive approach to defining institutional responses is vital if sexual violence policies are to be inclusive of diverse genders (Iverson \& Issadore, 2018). This can be done by simple acts such as reviewing the language used in policies and providing a variety of entry points for students who would like to raise concerns or make formal complaints.

Allow for flexible responses. Standardizing sexual violence policy is unsuitable for all institutions of higher education because it ignores local conditions (Iverson \& Issadore, 2018; 
Streng \& Kamimura, 2015). Where neoliberalism emphasizes standardization across contexts, fourth wave feminism emphasizes the importance of recognizing intersectional diversity and being cognizant of how different institutional contexts mean there can be no one-size policy that fits all institutions (Iverson \& Issadore, 2018). A second recommendation is thus to take situational context into account so that organizational policies can effect change at a local level (Dougherty \& Goldstein Hode, 2016; Iverson \& Issadore, 2018). Without focused attention on expanding organizational knowledge of the dynamics of sexual violence beyond the experiences of the dominant group, institutions of higher education risk perpetuating what Harris (2016) described as intersectional inequalities. The key here is to ensure that the policies each higher education institution adopts are relevant to its local context.

Become student allies and leaders for change. Amid a changing social and political environment, colleges and universities have an opportunity to demonstrate what it means to align institutional values and actions. To do so, institutions of higher education must radically improve their practices for addressing sexual violence. More specifically, institutions of higher education should strive to expand their ability to recognize and address the interactions of gender with systems such as sexism, racism, and heterosexism in the dynamics of sexual violence. Sexual violence is perpetuated within universities through tactics that relocate the problem away from the individual and the institution (Whitely \& Page, 2015). Therefore, institutions must be prepared to take greater institutional responsibility for what takes place on their campuses. This requires leaders at the highest level, and throughout the organization, to champion change in its various forms. In colleges and universities, presidents and senior executives must accept responsibility for setting the tone, expectations, and for accountability in alignment with institutional values. Rather than attempting to quell upset and manage an image of values 
alignment, we implore leadership to incorporate a commitment to accountability that includes student advocacy and efforts, and the development of spaces and platforms for fruitful dissent and engagement, both online and on campus, and that can serve as crucibles for challenge and change. To lead, university leadership at all levels must fully embrace the role of student ally over image-manager, and that includes a realistic view and vision of the university, as it is and as it could be.

Develop transformational practices. Some institutions fail to take enough measures to "protect the victim from any retaliation from the alleged perpetrator" (Cantalupo, 2011, p. 214). To do so requires an understanding of some of the unique considerations of the higher education environment. Unlike places of employment, colleges and universities are, for students, the places where they may live, socialize, and spend the majority of their time. Effective responses must consider the various, complex ways in which continued harassment or retaliation might occur. This failure by academic institutions to deal robustly and effectively with sexual violence is encouraging a new wave of feminist activism to confront the contradiction between espoused policies that seem to safeguard victims of sexual violence and their actual experiences. Yet policies, on their own, are not robust enough to address the conflict between a university's sense of itself as a just institution, and institutional negligence toward its students and other members of the institution. Acknowledging how sexual violence affects peoples' lives is vital for developing transformational practices, and is in line with fourth wave feminism's call for greater dialogue on issues of concern (Chamberlain, 2016). Furthermore, the strategies of fourth wave feminist activism allow a public unmasking of systemic oppression. This unmasking informs both micro and macro-level political action. By breaking the silence around sexual violence, 
fourth wave feminist action has the potential to not only challenge but also galvanize societal attitudes by highlighting gender-based injustices.

This article demonstrates how this fourth-wave feminist activism advances efforts to address gender-based sexual violence by highlighting persistent sex-based inequities in higher education, and offers insight into a new iteration of feminist theorizing and strategizing. Institutional practices must be alert to changing circumstances and grounded in reality rather than static institutional ideals. An overarching imperative is that higher education institutions must embrace organizational change to deal with the ongoing issue of sexual violence. To do so, the institutional enactment of policies and practices must be brought into better alignment with stated values. In conclusion, higher education institutions should focus far less on institutional documents and much more on institutional doings that demonstrate a commitment to eradicating all forms of violence on campus, and beyond.

Postscript: $\quad$ This paper was written over the course of approximately three years. While the authors have attempted revisions to keep the conversation current, they recognize that this is a rapidly changing landscape.

Sth Social Sciences and Humanities Research Council of Canada
Conseil de recherches en sciences humaines du Canada

\section{Canadä}

This research received partial support from the Social Sciences and Humanities Research Council of Canada. 
POLITICS VERSUS POLICIES 


\section{References}

Ahmed, S. (2006). The nonperformativity of Antiracism. Meridians: feminism, race, transnationalism, 7(1), 104-126. Retrieved from https://www.jstor.org/stable/40338719

Ahmed, S. (2007). 'You end up doing the document rather than doing the doing': Diversity, race equality and the politics of documentation. Ethnic and Racial Studies, 30(4), 590-609. https://doi.org/10.1080/01419870701356015

Ahmed, S. (2015, December 3). Sexual harassment [Web log post]. Retrieved from https://feministkilljoys.com/2015/12/03/sexual-harassment/ Ahmed, S. (2017). Living a Feminist Life. Durham, NC: Duke University Press.

Alani, T., \& Jeffery, N. (2015). Responding to sexual assault on Canadian university campuses: Promising policies and future directions. Psynopsis, 37(2), 16-17. Retrieved from https://www.cpa.ca/docs/File/Psynopsis/2015/PsynopsisSpring2015WEB.pdf

Bacchi, C. L. (1999). Women, Policy and Politics: The Construction of Policy Problems. Thousand Oaks, CA \& London: Sage Publications.

Bacchi, C. (2009). Analysing policy: What's the problem represented to be? Frenchs Forest, NSW: Pearson.

Bacchi, C. \& Goodwin, S. (2016). Poststructural policy analysis. New York \& London: Palgrave MacMillan.

Baer, H. (2015). Redoing feminism: digital activism, body politics, and neoliberalism. Feminist Media Studies, 16(1), 17-34. https://doi.org/10.1080/14680777.2015.1093070

Baker, C. (2008). The Women's Movement against Sexual Harassment. New York, NY: Cambridge University Press.

Baker, K. J. M. (2016, June 3). Here is the powerful letter the Stanford victim read aloud to her attacker. BuzzFeed News. Retrieved from 
https://www.buzzfeednews.com/article/katiejmbaker/heres-the-powerful-letter-thestanford-victim-read-to-her-ra

Barca, L. A. (2018). The agency factor: Neoliberal configurations of risk in news discourse on the Steubenville, Ohio rape case. Critical Discourse Studies, 15(3), 265-284. https://doi.org/10.1080/17405904.2017.1408476

Baumgardner, J. (2011). Is there a fourth wave? Does it matter?. In F'em: Goo, gaga and some thoughts on balls. Retrieved from http://www.feminist.com/resources/artspeech/genwom/baumgardner2011.html

Brown, S. (2017, June 25). In the time of Trump, colleges start to 'Make Title IX Our Own' The Chronicle of Higher Education. Retrieved from http://www.chronicle.com/article/In-the-Time-of-Trump-Colleges/240434

Browne, R. (2014, October 30). Why don't Canadian universities want to talk about sexual assault? Macleans. Retrieved from http://www.macleans.ca/education/unirankings/whydont-canadian-universities-want-totalk-about-sexual-assault/

Burleigh, N. (2014, June 19). Confronting campus rape. Rolling Stone. Retrieved from http://www.rollingstone.com/politics/news/confronting-campus-rape-20140604

Cantalupo, N.C. (2011). Burying our heads in the sand: Lack of knowledge, knowledge avoidance and the persistent problem of campus peer sexual violence. Loyola University Chicago Law Journal, 43(1), 205-266. Retrieved from https://lawecommons.luc.edu/cgi/viewcontent.cgi?article=1028\&context=luclj

Cantalupo, N. C. (2016). Title IX's civil rights approach and the criminal justice system: 
Enabling separate but coordinated parallel proceedings. In S. C. Wooten \& R. W. Mitchell (Eds.), The crisis of campus sexual violence: Critical perspectives on prevention and response (pp.125-147). New York, NY: Routledge.

Chamberlain, P. (2016). Affective temporality: Towards a fourth wave. Gender and Education, 28(3), 458-464. https://doi.org/10.1080/09540253.2016.1169249

Chiose, S. (2016, April 2). Justice on campus. The Globe and Mail. Retrieved from http://www.theglobeandmail.com/news/national/education/canadian-universitiesunderpressure-to-formalize-harassment-assaultpolicies/article29499302/

Cochrane, K. (2013a). All the rebel women: The rise of the fourth wave of feminism [Kindle version]. Retrieved from Amazon.com

Cochrane, K. (2013b, December 10). The fourth wave of feminism: meet the rebel women. The Guardian. Retrieved from https://www.theguardian.com/world/2013/dec/10/fourth-wavefeminism-rebel-women

DeGue, S., Valle, L. A., Holt, M. K., Massetti, G. M., Matjasko, J. L., \& Tharp, A. T. (2014). A systematic review of primary prevention strategies for sexual violence perpetration. Aggression and Violent Behavior, 19(4), 346-362. https://doi.org/10.1016/j.avb.2014.05.004

Donnelly, A. (2016, September 14). Mustafa Ururyar gets 18 months in jail for sexually assaulting fellow York university PhD student Mandi Gray. The National Post. from http://news.nationalpost.com/toronto/mustafa-ururyar-sentenced

Dougherty, D. S., \& Goldstein Hode, M. (2016). Binary logic and the discursive interpretation of organizational policy: Making meaning of sexual harassment policy. Human Relations, 69(8), 1729-1755. https://doi.org/10.1177/0018726715624956 
Dwoskin, E., \& Svrluga, S. (2016, June 9). 'We're horrified': At Stanford, the impact of a sexual assault is searing. The Washington Post. Retrieved from https://www.washingtonpost.com/local/education/were-horrified-at-stanford-theimpactof-a-sexual-assault-is-searing/2016/06/09/6628dc08-2e85-11e6b5dbe9bc84a2c8e4_story.html

Harris, K. L. (2016). Re-situating organizational knowledge: Violence, intersectionality and the privilege of partial perspective. Human Relations, 70(3), 263-285. doi: $10.1177 / 0018726716654745$.

Hasham, A. (2017, March 14). Judge's 'unusual approach' in Mandy Gray sex assault trial questioned. The Toronto Star. Retrieved from https://www.thestar.com/news/gta/2017/03/14/toronto-man-appealing-sexassaultconviction-in-mandi-gray-case-says-judge-was-biased.html

Hoffman, K. (2015a, March 3). Exclusive: York University fails to support sex assault victims, woman says. CBC News. Retrieved from http://www.cbc.ca/news/canada/manitoba/yorkuniversity-fails-to-support-sexassault-victims-woman-says-1.2979396

Hoffman, K. (2015b, June 30). York University's sexual assault policy sparks human-rights complaint. The Globe and Mail. Retrieved from http://www.theglobeandmail.com/news/national/education/york-universityssexualassault-policy-sparks-human-rights-complaint/article25194134/

Iverson, S. V. (2006). Performing gender: A discourse analysis of theatre-based sexual violence prevention programs. NASPA Journal, 43(3), 547-571. doi: 10.2202/1949-6605.1683

Iverson, S. V., \& Issadore, M. N. (2018). Going Upstream: Policy as sexual violence prevention and response. New Directions for Student Services, 161, 59-69. doi: 
$10.100 \mathrm{~s} / \mathrm{ss} .20253$.

Jessup-Anger, J., Lopez, E., \& Koss, M. P. (2018). History of sexual violence in higher education. New Directions for Student Services, 161, 9-19. doi: 10.1002/ss.20249

Kane, L. (2016, March 7). Sexual assault policies lacking at most Canadian universities, say students. CBC News British Columbia. Retrieved from http://www.cbc.ca/news/canada/british-columbia/canadian-universities-sex assaultpolicies-1.3479314

Krause, K. H., Miedema, S. S., Woofter, R., \& Yount, K. M. (2017). Feminist research with student activists: Enhancing campus sexual assault research. Family Relations, 66(1), 211-223. https://doi.org/10.1111/fare.12239

La Ganga, M. L., \& Levin, S. (2016, June 11). Stanford sexual assault: Students plan graduation protest as anger grows. The Guardian. Retrieved from https://www.theguardian.com/usnews/2016/jun/11/stanford-sexual-assault-students-plangraduation-protest-as-angergrows

Lazar, M. M. (2007). Feminist critical discourse analysis: Articulating a feminist discourse praxis. Critical discourse studies, 4(2), 141-164. https://doi.org/10.1080/17405900701464816

Levin, J. S., Aliyeva, A., \& Walker, L. (2016). From community college to university: Institutionalization and neoliberalism in British Columbia and Alberta. Canadian Journal of Higher Education, 46(2), 165-180. Retrieved from: http://journals.sfu.ca/cjhe/index.php/cjhe/article/view/185905/pdf_1

McGillivray, K. (2017, March 14). 150 sex assault survivors send government \$7 M in 'invoices'. CBC News. Retrieved from http://www.cbc.ca/news/canada/toronto/cost-of- 
sexualassault-mandi-gray-1.4023173

Mehta, D. (2016, November 9). Mandi Gray to raise issues with York University's new sexual violence policy. The Toronto Star. Retrieved from https://www.thestar.com/news/gta/2016/11/09/mandi-gray-to-raise-issues-withyorkuniversitys-new-sexual-violence-policy.html

Munro, E. (2013). Feminism: A fourth wave? Political Insight, 4(2), 22-25. doi: $10.1111 / 2041-9066.12021$

Nelson, G. (2015, June 23). The high cost of sexual assaults on college campuses. Nonprofit quarterly. Retrieved from https://nonprofitquarterly.org/2015/06/23/the-high-cost-ofsexual-assaults-on-college-campuses/

Quinlan, E. (2017). Institutional betrayal and sexual violence in the corporate university, (pp. 6179). In E. Quinlan, A. Quinlan, C. Foget \& G. Taylor, (Eds.) Sexual violence at Canadian universities: Activism, institutional responses, and strategies for change. Waterloo, CA: Wilfred Laurier Press.

Rentschler, C. (2014). Rape culture and the feminist politics of social media. Girlhood Studies, 7(1), 65-82. https://doi.org/10.3167/ghs.2014.070106

Ropers-Huilman, R., Williamsen, K. M., \& Hoffman, G. D. (2016). Afterword. Questioning the scripts of sexual misconduct. In S. C. Wooten \& R. W. Mitchell, (Eds.), The crisis of campus sexual violence: Critical perspectives on prevention and response (pp. 192-197). New York, NY: Routledge.

Sanchez, R. (2016, June 11). Stanford rape case: Inside the court documents. CNN. Retrieved from http://www.cnn.com/2016/06/10/us/stanford-rape-case-court-documents/ Sharp, E. A., Weaver, S. E., \& Zvonkovic, A. (2017). Introduction to the special issue: Feminist 
framings of sexual violence on college campuses. Family Relations, 66, 7-16. https://doi.org/10.1111/fare.12242

Sinozich, S., \& Langton, L. (2014). Special report: Rape and sexual assault victimization among college-age females, 1995-2013. Washington DC: United States Department of Justice. Retrieved from http://www.bjs.gov/content/pub/pdf/rsavcaf9513.pdf

Smith, C. P., \& Freyd, J. J. (2014). Institutional betrayal. American Psychologist, 69(6), 575587. http://dx.doi.org/10.1037/a0037564

Solomon, D. (2009, November 13). Fourth-wave feminism: Questions for Jessica Valenti. The New York Times Magazine. Retrieved from http://www.nytimes.com/2009/11/15/magazine/15fob-q4-t.html

Spencer, C., Mallory, A., Toews, M., Stith, S., \& Wood, L. (2017). Why sexual assault survivors do not report to universities: A feminist analysis. Family Relations, 66(1), 166-179. http://dx.doi.org/10.111/fare.12241

Stanford University. (n.d). A history of Stanford. Retrieved from https://www.stanford.edu/about/history/

Stanford University Communications. (2016, June 6). Stanford University statement regarding Brock Turner case. Stanford News. Retrieved from https://news.stanford.edu/2016/06/06/stanford-university-statement-regarding-brockturner-case/

Streng, T. K., \& Kamimura, A. (2015). Sexual assault prevention and reporting on college campuses in the US: A review of policies and recommendations. Journal of Education and Practice, 6(3), 65-71. Retrieved from https://files.eric.ed.gov/fulltext/EJ1083737.pdf Tamburri, R., \& Samson, N. (2014, October 20). Ending sexual violence on campus. University 
Affairs. Retrieved from http://www.universityaffairs.ca/features/feature- article/ending sexual-violence-campus/

United States Department of Education. (2014). Campus safety and security data analysis. Washington, DC: United States Department of Education. Retrieved from http://ope.ed.gov/campussafety/Trend/public/\#/answer/3/301/table/?row=7\&column=1

Ward, L., \& Shahzad, R. (2016, July 21). York University PhD student guilty in sex assault of student Mandi Gray. CBC News. Retrieved from http://www.cbc.ca/news/canada/toronto/york-sex-assault-guilty-1.3689325

Weikle, B. (2016, September 13). Universities face increasing pressure to address campus sexual assault. CBC News. Retrieved from http://www.cbc.ca/news/canada/campus-sexualassault-1.3750355

Whitley, L., \& Page, T. (2015). Sexism at the Centre: Locating the Problem of Sexual Harassment. New Formations, 86, 34-53. doi: 10.3898/NEWF.86.02.2015

Wodak, R. (2011). Critical discourse analysis. In K. Hyland \& B. Paltridge (Eds.), The Bloomsbury companion to discourse analysis (pp. 38-54). London, UK: Bloomsbury.

Wooten, S. C. (2016). Heterosexist discourses: How feminist theory shaped campus sexual violence policy. In S. C. Wooten \& R. W. Mitchell (Eds.), The crisis of campus sexual violence: Critical perspectives on prevention and response (pp.33-53). New York, NY: Routledge.

Wooten, S. C., \& Mitchell, R. W. (Eds.). (2016). The crisis of campus sexual violence: Critical perspectives on prevention and response. New York, NY: Routledge.

Wrye, H. K. (2009). The fourth wave of feminism: Psychoanalytic perspectives introductory remarks. Studies in Gender and Sexuality, 10(4), 185-189. 
https://doi.org/10.1080/15240650903227999

York University. (n.d.). A short history of York. Retrieved from http://president.yorku.ca/about/ 